\title{
Okun's Law Revisited: Evidence From OECD Countries
}

B. Moazzami, Lakehead University, Canada

B. Dadgostar, Lakehead University, Canada

\begin{abstract}
Okun's law is one of the most enduring stylistic facts in macroeconomics. The inverse relationship between the unemployment rate and the growth rate of real output, known as Okun's law, has important implications for macroeconomic policy, particularly in determining the optimal and desirable growth rate of output. This paper examines this relationship within an error correction modelling framework which tests the relationship as a long-run relationship while allowing shortrun deviations from long-run equilibrium to take place. Using quarterly data for 13 OECD countries covering the period from 1988.I to 2007:IV, we find overwhelming support for Okun's law.
\end{abstract}

Keywords: Okun's Law, unemployment and growth rate of retail output, long run and short run model

\section{INTRODUCTION}

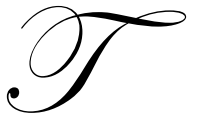

he inverse relationship between the unemployment rate and the growth rate of real output is known as Okun's law. Okun promised large rewards in output for any reduction in unemployment. This relationship that appears to be a robust empirical regularity has received significant attention in the literature. Many researchers have re-examined this relationship and obtained mixed results. ${ }^{1}$ However, the main problem in the existing research is that they do not generally distinguish between short- and long-run impacts of output growth on unemployment. In general, most researchers obtained negative and significant coefficient on cyclical output. The magnitude of this coefficient has been very sensitive to a number of factors, including model specification, estimation method and the sample period used. The present paper suggests that the Okun's law should be regarded as a long-run relationship and be tested within a framework that allows for a long-run steady state equilibrium relationship while allowing for short-term deviations to take place.

\section{MODEL SPECIFICATION}

Following Parchowny (1993), we define the relationship between unemployment and output as:

$\left(\mathrm{u}-\mathrm{u}^{*}\right)=-\delta\left(\mathrm{y}-\mathrm{y}^{*}\right)+\beta \mathrm{Z}$

Or,

$u^{c}=-\delta y^{c}+\beta Z+\varepsilon$

Where $u^{c}$ is the cyclical unemployment rate, the difference between the observed unemployment rate and the natural rate and $\mathrm{y}^{\mathrm{c}}$ is the $\log$ output ratio defined as the ratio of actual output to the potential or trend level of output. Okun's coefficient is captured by the positive parameter of $\delta$. Furthermore, $\mathrm{Z}$ represents a vector of other

\footnotetext{
1 See Knoester (1986), Kauman (1988), Prachowny (1993), Mankiw (1994), Weber (1995), Moosa (1997), Attfield and Silverstone (1997, 1998), Lee Jim (2000), Freeman (2000) and Adanu (2005).
} 
variables that are appropriate in determining the unemployment gap. ${ }^{2}$ Using an equation similar to equation (2), Okun (1962) estimated $\delta$ to be close to 0.32 , implying that one percent reduction in unemployment rate results in about 3.2 percent increase in real output.

Equation (2) represents a long-term relationship between unemployment and real output. To allow for short-term deviations from this long-run relationship, Gordon (1984) and Evans (1989) used autoregressivedistributed lag models to estimate the lagged effects of output growth on the unemployment rate. They specified a dynamic relationship such as such:

$\mathrm{u}^{\mathrm{c}}=\sum_{i=1}^{k} \alpha_{\mathrm{i}} \mathrm{u}_{\mathrm{t}-\mathrm{i}}^{\mathrm{c}}+\sum_{i=0}^{m} \theta_{\mathrm{i}} \mathrm{y}_{\mathrm{t}-\mathrm{i}}^{\mathrm{c}}+\varepsilon_{\mathrm{i}}$

Using equation (3), the long-run impact of a change in $y^{c}$ on $u^{c}$ is:

$\omega=\left(\sum_{i=0}^{m} \theta_{\mathrm{i}}\right) /\left(1-\sum_{i=1}^{k} \alpha_{\mathrm{i}}\right)$

To estimate the long-run coefficient $\omega$, one has to estimate equation (3) and then calculate the long-run impact of output growth on unemployment. ${ }^{3}$ The above two step procedure is computationally inefficient since we have not only to calculate the long-run coefficient $\omega$, but also have to compute its standard error. Clearly, it would be better if we could estimate $\omega$ along with its standard error directly. This can be done by using an extended version of the transformation proposed by Wickens and Breusch (1988). ${ }^{4}$ Following them, we can transform this equation (3) as:

$$
\begin{aligned}
& \Delta \mathrm{u}^{\mathrm{c}}=\lambda_{0}-\sum_{i=1}^{k-1}\left(\sum_{j=i+1}^{k} \alpha_{\mathrm{i}}\right) \Delta \mathrm{u}_{\mathrm{t}-\mathrm{i}}^{\mathrm{c}}+\theta_{0} \Delta \mathrm{y}_{\mathrm{t}}^{\mathrm{c}}-\sum_{i=1}^{m-1} \quad\left(\sum_{j=i+1}^{m} \quad \theta_{\mathrm{i}}\right) \Delta \mathrm{y}_{\mathrm{t}-\mathrm{i}}^{\mathrm{c}}- \\
& \left(1-\sum_{i=1}^{k} \alpha_{\mathrm{i}}\right)\left(\mathrm{u}_{\mathrm{t}-1}^{\mathrm{c}}-\omega \mathrm{y}_{\mathrm{t}-1}^{\mathrm{c}}\right)+\varepsilon_{\mathrm{t}}
\end{aligned}
$$

Equation (5) is an extended version of the error correction model popularized by Hendry (1986). The transformation (5) suggests that changes in the unemployment rate, over time, are due to two sources. First, they respond, with a lag, to changes in the output growth. Second, they respond to deviation from their long-term relationship captured by the last term in (5). Equation (5) is in the error correction form and suggests that $\left(\begin{array}{ll}1-\sum_{i=1}^{k} & \alpha_{\mathrm{i}}\end{array}\right)$ of the disequilibrium between the unemployment rate and output growth is adjusted for in each period. The impact effect of changes in real output on unemployment is captured by $\theta_{0}$. Estimating equation (5), we can directly obtain the short-run multiplier $\theta_{0}$ along with the long-run multiplier wand the speed of adjustment.

\section{THE DATA}

Before proceeding with the estimation of model (5), a brief discussion of the data is in order. Quarterly data covering the period from 1988.I to 2007:IV have been obtained for Austria, Australia, Canada, Finland, France, Greece, Germany, Italy, Korea, Norway, New Zealand, United Kingdom and the United States. The main problem in estimating (5) lies in measuring $\mathrm{y}^{\mathrm{c}}$ and $\mathrm{u}^{\mathrm{c}}$, which are unobservable. To rectify this problem we follow Perron (1989) in measuring $y^{c}$ and Evans (1989) and Perron (1990) in measuring $u^{c}$. Perron (1989) shows that deviation of log post-war US real GNP from a deterministic trend with a break in the trend coefficient during 1973 is stationary. Deviation of the post-war US unemployment rate from a mean level which changes between the third and fourth quarters of 1973 is also stationary. We allowed for log potential output and the unemployment rate to undergo a break during the 1980s. After allowing for a possible break, all series appeared to be stationary. Note that standard methods can be applied to equation (5) even if $u^{c}$ and $y^{c}$ are integrated of degree one but are cointegrated. We test the residual of the estimated equations for stationarity.

\footnotetext{
${ }^{2}$ Parchowny M. F. J. (1993). "Okun's Law: Theoretical foundations and revised estimates”, Review of Economic and Statistics. Vol. 24. p. 332.

${ }^{3}$ Using this procedure, Gordon (1984) estimated the long-run Okun's coefficient to be around 0.5.

${ }^{4}$ Also see Moazzami (1999).
} 


\section{THE RESULTS}

To obtain estimates of the short- and long-run impact of changes in output growth on the unemployment rate, we estimated equation (5) for all countries using a maximum likelihood estimator. To estimate equation (5), we have to specify the lag length for the first-differenced variables. Following Gilbert (1986), we over-parameterized the model and then used a series of F-tests along with the Akaike's FPE as our selection criterion. Table 1 reports the result of maximum likelihood (ML) estimation of model (5). Figures in parentheses represent t-statistics. The starting values for the ML iterations were set equal to the estimated parameters from the OLS regression of the unrestricted model.

To ensure the validity of the estimated results for statistical inference, the estimated models were subjected to a series of diagnostic tests. The Dickey-Fuller (DF) test is used to test for the presence of a unit root in the residuals. All values of the DF test were below the critical limit. The presence of autocorrelation was tested using a Lagrange Multiplier test proposed by Breusch and Godfrey (1981). No evidence of autocorrelation in the residuals was found.

Table 1

Estimation Results

\begin{tabular}{|c|c|c|c|c|}
\hline Countries & $\boldsymbol{\theta}_{\mathbf{0}}$ & $\boldsymbol{\omega}$ & $\mathbf{( 1 - \Sigma \mathbf { a } _ { \mathbf { i } } )}$ & $\mathbf{R}^{\mathbf{2}}$ \\
\hline Australia & $-0.23(2.37)$ & $-0.33(4.67)$ & $0.10(2.21)$ & 0.69 \\
\hline Austria & $-0.17(1.99)$ & $-0.31(3.45)$ & $0.07(3.21)$ & 0.67 \\
\hline Canada & $-0.26(2.02)$ & $-0.47(5.67)$ & $0.11(2.95)$ & 0.68 \\
\hline Finland & $-0.29(2.28)$ & $-0.41(3.75)$ & $0.05(3.12)$ & 0.65 \\
\hline France & $-0.15(3.12)$ & $-0.35(7.23)$ & $0.07(2.21)$ & 0.56 \\
\hline Germany & $-0.35(1.92)$ & $-0.38(3.45)$ & $0.09(3.45)$ & 0.49 \\
\hline Greece & $-0.19(1.95)$ & $-0.34(4.23)$ & $0.07(2.11)$ & 0.43 \\
\hline Italy & $-0.15(1.89)$ & $-0.28(2.29)$ & $0.10(2.23)$ & 0.45 \\
\hline Korea & $-0.17(2.11)$ & $-0.26(3.22)$ & $0.09(3.22)$ & 0.51 \\
\hline Norway & $-0.28(1.95)$ & $-0.42(4.23)$ & $0.08(4.32)$ & 0.41 \\
\hline New Zealand & $-0.21(1.89)$ & $-0.31(2.21)$ & $0.06(2.24)$ & 0.39 \\
\hline U.K. & $-0.29(2.21)$ & $-0.37(3.21)$ & $0.09(2.27)$ & 0.57 \\
\hline U.S. & $-0.32(1.99)$ & $-0.46(4.23)$ & $0.10(4.45)$ & 0.68 \\
\hline
\end{tabular}

Turning to the results, we observe that the short- and long-run coefficients have the correct signs and are highly significant. The adjustment coefficients have the correct sign and are highly significant. The short-run coefficients appear to be smaller than the long-term ones. The long-run coefficients range from 0.26 for Korea to 0.47 for Canada.

\section{CONCLUSION}

This paper examined the relationship between growth rate of real output and unemployment using a error correction model. The advantage of this model over the other models used to test Okun's law is that we can test the long run relationship between output and unemployment while allowing short run deviations from long run equilibriums to take place.

The results suggest that there are significant short- and long-run tradeoffs between unemployment and output growth. Reducing the unemployment rate by $1 \%$ would result in $2.6 \%$ to $4.7 \%$ growth in output in countries under study. The highest short-and long-run coefficients are for Canada, Finland, Norway and the United States, suggesting that employment is more responsive to economic growth in those countries.

\section{AUTHOR INFORMATION}

Dr. Bahram Dadgostar is a Full Professor of Economics and Finance at Lakehead University, Thunder Bay, Ontario, Canada. Dr. Dadgostar has a balanced record of activity and achievement in all areas of academic life. His research and teaching career reflects an avid interest in some diverse areas, including economic theory, international 
finance and corporate finance. On the research front his record in research and publication demonstrates an active contribution to scholarly knowledge in his field. He has produced a number of studies on different countries. Notable among those are: consumer Demand for Food Commodities in Thailand, ARCH and GARCH Effect in Daily Stock Returns and Does Government Expenditure Matter.

Dr. Bakhtiar Moazzami is a Full Professor of Economics at Lakehead University, Thunder Bay, Ontario, Canada. $\mathrm{He}$ is a known expert on regional economic development. Dr. Moazzami has written extensively on Aboriginal economics development issues. He has developed a demographical forecasting model capable of predicting age, sex and migration specific population trends in various Aboriginal communities. His publications in the area of index number theory and economic development is significant. He has produced a number of students and books. Notable among these are: Interest Rate and Budget Deficit, Stock Return and Inflation, and Lending Rate Stickiness of Monetary Transmission.

\section{REFERENCES}

1. Adanu, Kwami. (2005) "A Cross-province comparison of Okun's coefficient for Canada". Victoria B.C., Canada.

2. Attfield Clifford L. F., and Brian Silverstone. (1997) " Okun's Law Revisited: Should we worry about low unemployment?". Federal Reserve Bank of Cleveland Economic Commentary.

3. Attfield, Clifford L. F., and Brian Silverstone. (1998) "Okun's Law,Cointegration and Gap Variables". Journal of Macroeconomics. Vol. 20, No. 3.

4. Breusch, T. S. And Godfrey, L. (1981), A review of recent work on testing for autocorrelation in dynamic simultaneous models, in (Eds) D. Currie, R. Norway and D. Peel, Macroeconomic Analysis, Croom-Helm, London.

5. Evans, G. W. (1989), Output and unemployment dynamics in the United States: 1950-1985, Journal of Applied Econometrics, 4, 213-238.

6. Freeman, Donald G.(2001) "Panel Test of Okun's Law for Ten Industrial Countries". Economic Inquiry, Vol. 39, No. 4. (Oct. 2001), pp.511-523.

7. Gilbert, C. L. (1986), Practitioners corner: Professor Hendry's econometric methodology, Oxford Bulletin of Economics and Statistics, 48 (3), 283-307.

8. Gordon, R.J. (1984), Unemployment and potential output in the 1980s, Brookings Papers on economic Activity, 15, 537-564.

9. Hendry, D.F. (1986), Econometric modelling with cointegrated variables: an overview, Oxford Bulletin of Economics and Statistics, 48 (3), 2001-11.

10. Knoster, A. (1986) “Okun's Law Revisited”, weltwirtschaftliches Archives, No. 122(4), pp.657-66.

11. Lee, Jim.(2000) "The Robustness of okun's Law: Evidence from OECD Countries". Journal of Macroeconomics Vol. 22.

12. Mankiw, N. Gregory (1994), "Macroeconomics". New York: Worth Publishers.

13. Moazzami B., Lending rate stickiness and monetary transmission mechanism: the case of Canada and the United States, Applied Financial Economics, 1999, 9, 533-538.

14. Moosa, Imad A.(1997) "A Cross-country comparison of Okun's Coefficient". Victoria: April 26, 1996. Journal of Economic Literature, Victoria: April 26. 1996

15. Okun, Arthur M. (1970) "Potential GNP: its measurement and significance". Washington: American Statistical Association, Brookings Institute.

16. Parchowny M. F. J.(1993) “Okun's Law: Theoretical foundations and revised estimates”. Review of Economic and Statistics. Vol. 24.

17. Perron, P. (1989), The Great crash, the oil price shock, and the unit root hypothesis, Econometrica, 57, 1361-1402.

18. Perron, P. (1990), Testing for unit roots in a time series with a changing mean, Journal of Business and Economic Statistics, 8, 153-162.

19. Weber, C.E. (1995) ."Cyclical Output, Cyclical Unemployment, and Okun's Coefficient: a new structural approach." Journal of Applied Econometrics, Vol. 10, pp.433-445.

20. Wickens, M.R. and Breusch, T.S. (1988), Dynamic specification, the long-run and the estimation of transformed regression models, Economic Journal, 98, 189-205. 